\title{
Genetic Variability, Heritability and Genetic Advance in Rice (Oryza sativa L.) under Salt Affected Soil
}

\author{
Hamsa Poorna Prakash*, O.P. Verma and Amit Kumar Chaudhary
}

Department of Genetics and Plant Breeding, Narendra Deva University of Agriculture and Technology, Narendra Nagar Kumarganj, Faizabad-224-229 (Uttar Pradesh), India

*Corresponding author

\begin{tabular}{|l|}
\hline K e y w o r d s \\
$\begin{array}{l}\text { Rice, Genetic variability, } \\
\text { Heritability, Genetic } \\
\text { advance, Salt affected soil }\end{array}$ \\
\hline Article Info \\
\hline $\begin{array}{l}\text { Accepted: } \\
22 \text { April } 2018 \\
\text { Available Online: } \\
\text { 10 May } 2018\end{array}$ \\
\hline
\end{tabular}

\section{Introduction}

Rice belongs to the sub-family Oryzoidae of family Poaceae, genus Oryza and tribe Hordae. Cultivated rice is annual grass with round, hollow and jointed culms, flat leaves, fibrous root system and terminal inflorescence which are referred as panicle composed of spikelets. The flower is autogamous which
The present investigation entitled "Genetic variability, heritability and genetic advance in rice (Oryza sativa L.) under salt affected soil" comprised of 7 lines and 3 testers recommended for sodic soil. Crosses were made in "line x tester mating design. Thus 21 crosses $\left(F_{1}\right.$ 's) were produced during 2015 . All crosses along with their 10 parents and one check (Usar Dhan-3) were evaluated in RBD with three replications during Kharif 2016. Observation were recorded for Days to 50\% flowering, Plant height $(\mathrm{cm})$, Flag leaf area $\left(\mathrm{cm}^{2}\right)$, Panicle bearing tillers per plant, Panicle length $(\mathrm{cm})$, Grains per panicle, 1000-grain weight (g), Biological yield per plant (g), Harvest-index (\%) and Grain yield per plant (g). Analysis of variance that mean sum of squares due to treatments, parents and crosses had significant differences, whereas, significance of parent vs. crosses indicated the presence of heterotic effects in crosses. High value of phenotypic coefficients of variability (PCV) and genotypic coefficients of variability $(\mathrm{GCV})$ was found for grain yield per plant and biological yield per plant indicating existence of wide spectrum of variability for these traits and greater opportunities for desired gain through phenotypic selection. Heritability in broad sense was observed $(>75 \%)$ for majority of traits. High value of heritability in narrow sense $(>30 \%)$ was recorded for all traits with genetic advance indicating preponderance of additive gene effects. Analysis of variance revealed relative contribution of line effect is higher than $\mathrm{L} \times \mathrm{T}$ effect for all characters and Tester effect is higher than Line effect for all traits confirming predominant role of non-additive gene action in the inheritance of all the characters studied. 
extend up to 7-10 days. Though it is selfpollinated extent of natural crossing varies from 0-3\% (Poehlman, 1987).

The cultivated species are Oryza glaberrima and Oryza sativa. Both the cultivated species of rice are diploid $(2 \mathrm{n}=24)$. Oryza glaberrima, an annual species originated and cultivated in West Africa form the past 3500 years. While Oryza sativa is grown all over the world and commonly grown in Asia. Found to be originated in foot hills of Himalayas. It has round, jointed culm and long narrow leaves. The culm terminates in an inflorescence called panicle. The height of culm may vary from $20 \mathrm{~cm}$ to over $5 \mathrm{~m}$ in some deep-water rice exhibiting excellent internode elongation ability.

Rice is an excellent source of carbohydrates and also rich in magnesium, thiamine, niacin, phosphorus, vitamin $\mathrm{B}_{6}$, zinc and copper. Some varieties have iron, potassium and folic acid. Some varieties may provide $14 \mathrm{~g}$ of protein per $100 \mathrm{~g}$. The varieties of rice are typically classified as long, medium, and short-grained. The grains of long-grain rice (high in amylose) tend to remain intact after cooking; medium-grain rice (high in amylopectin) becomes stickier. Some varieties of long-grain rice are high in amylopectin, known as Thai Sticky rice. Medium-grain rice is used for sweet dishes, for risotto in Italy, and many rice dishes, such as arròsnegre, in Spain. Rice flour does not contain gluten, so is suitable for people on a gluten-free diet.

Rice is one of the important food crops that feed almost one fifth of the world's population 65 per cent of the global population and forms the cheapest source of food, energy and protein (Khush, 1997). About 90 per cent of the rice in the world is grown in Asia (nearly 640 million tons). Sub-Saharan Africa produces about 19 million tonnes and Latin America some 25 million tonnes. Rice is grown in about $154 \mathrm{~m}$. ha annually occupying about 11 per cent of the world's arable land. Developing countries are responsible for approximately 95 per cent of rice production and 85 per cent of rice exports. Agriculture is the mainstay of the Indian economy and contributes nearly 14.1 per cent of GDP (Economic survey, 2012-13), as about 65-70 per cent of the population is dependent on agriculture for their livelihood. Rice is the staple food for more than 60 per cent of the total population in India. The production of rice in the year 2009-10 was to the tune of 89.2 million tonnes constituting about 52 per cent of the total food grain production of India (FAOSTAT, 2014). Although country has witnessed considerable increase in rice production and productivity from $668 \mathrm{~kg} / \mathrm{ha}$ in 1951 to $2066 \mathrm{~kg} / \mathrm{ha}$ in $2011-12$.

This increase has not been able to keep pace with the growing demand of the Indian population. It is estimated that rice production has to increase by 38 per cent by 2030 to feed the accelerating human population (International Food Policy Research Institute, 2010). The challenge, above anything else, is to produce this additional rice with less land, less water, and less labour, in more efficient, environmentally-friendly production systems that are more resilient to climate change, among other factors. In world, the production of rice is about 471.83 million tonnes (201516). In India area, production and productivity of rice is about 43.85 million hectares, 104.32 million tonnes and $2404 \mathrm{~kg}$ per hectare, respectively (Anonymous, 2015-16). Uttar Pradesh is an important rice growing state in the country. Agriculture is the most important in the state, because, about $80 \%$ of its population resides in rural areas and $75 \%$ of the total workers are involved directly or indirectly in cultivation/farming which accounts for $27 \%$ of state's GDP. Agriculture is the main source of income for families in the state. It has 11.56 million hectare of 
cultivated area, constituting $70 \%$ of the total geographical area. The irrigated area is over 13.43 million hectare. Rice area with salt problem in state is estimated to be $\leq 2 \%$. Inland salinity areas are mainly concentrated in Raibareilly, Azamgarh, Sultanpur, Faizabad, Lucknow, Unnao and Pratapgarh district. The area and production of rice in this state is about 5.87 million hectare and 12.22 million tonnes, respectively and productivity of $2082 \mathrm{~kg}$ per hectare (Anonymous, 201516).

The success of good breeding programme usually depends upon the genetic variability present in the breeding materials. Thus, knowledge on genetic variability, heritability and genetic advance is essential for a breeder to choose good genotypes for crop improvement.

At present in the country an estimated $8.9 \mathrm{~m}$ ha of land is affected by salt of which U.P share $1.29 \mathrm{~m}$ ha. It has been estimated that increasing salinization caused by agricultural practices may lead to a loss of $30 \%$ of arable land by 2025, which may climb up to divesting $50 \%$ by 2050 . So it is very essential to develop elite genotypes which are suitable to saline-alkaline soil.

\section{Materials and Methods}

The present investigation was carried out at the Research Farm of Department of Genetics and Plant Breeding, N.D. University of Agriculture \& Technology, Narendra Nagar and(Kumarganj), Faizabad during kharif, 2016. Geographically this place is located in between $26.47^{\circ} \mathrm{N}$ latitude and $82.12^{\circ} \mathrm{E}$ longitudes and at an altitude of 113 meters above from mean sea level. This area falls in sub-tropical climatic zone. The climate of district Faizabad is semi-arid with hot summer and cold winter. The soil of the experimental site was partially reclaimed sodic soil. $\{\mathrm{pH}=$
9.2; $\left.\mathrm{EC}=2.21\left(\mathrm{dSm}^{-1}\right) ; \mathrm{OC}=45 \%\right\}$ The details of weather conditions recorded during evaluation period of kharif, 2016 (11 ${ }^{\text {th }}$ June to $23^{\text {rd }}$ December).

The Experimental material consisted of a line $\mathrm{x}$ tester set of 21 hybrids $\left(\mathrm{F}_{1} \mathrm{~s}\right)$ developed by crossing 7 lines (females) with 3 testers (males) viz., Jaya, CSR-10 and BPT-5204 of high yielding genotypes/varieties suitable for saline-alkaline condition. The Seven lines were Narendra 2026, Pusa Basmati 1, Narendra 2009, FL 478, IR-12T-193, IR-11T205 and IR-12-193. The $21 \mathrm{~F}_{1} \mathrm{~S}$ along with their parents including one check NarendraUsar 3, was evaluated in randomized block design with three replications during kharif2016.

The seeds were sown on $11^{\text {th }}$ June, 2016 in separate plots and 21 days ( $2^{\text {nd }}$ July, 2016) old seedlings were transplanted in sodic soil as single seedling per hill in single row plot of 3 $\mathrm{m}$ length following $20 \times 15 \mathrm{~cm}$ spacing, respectively. All the recommended cultural practices were followed to raise a good crop.

The observations were recorded on five randomly selected competitive plants of a genotype in a plot in each replication for ten characters in the experiment. The mean values of observations recorded on five plants of each plot were used for analysis. The observations for different characters were recorded as follows:

The number of days taken from date of sowing to panicle emergence in $50 \%$ plants in a row plot was counted as days to $50 \%$ flowering. Plant height of a plant was recorded in centimeters from ground level to the tip of the main panicle excluding awns at maturity. The flag leaf area was calculated at maturity by measuring and multiplying the length and widest breadth of flag leaf and further multiplying the value by factor 0.75 . The 
number of panicle bearing tillers was counted in a plant at the time of maturity. The length of main panicle was measured in centimeters from the base to the tip of the panicle excluding awns. The total number of grains was counted in each panicle of a plant after harvesting the crop. The weight of 1000-filled grains sampled from five randomly selected plants taken in a plot was weighed in grams. The total biomass excluding roots of a plant was sun-dried and dry matter was weighed in grams. The ratio of grain yield per plant ( $\mathrm{g}$ ) to biological yield per plant (g) of a plant was considered as harvest-index and expressed in percentage. The grains of each selected plant were hand threshed and sun-dried. The weight of the grains obtained from a plant was taken on an electronic balance in grams.

The experimental data collected on all the ten characters in respect of experiment of the present study were compiled by taking the mean values over five randomly selected plants in each plot in each replication. It was then subjected to Analysis of variance for Randomized Complete Block Design (Panseand Sukhatme, 1967). The significance of differences among treatment means (parent and hybrids) was tested by 'F-test'.

The analysis of variance was further extended to partition the variance due to treatments (genotypes) in to various components such as parents, crosses, parents $v / s$ crosses, females, males and females $v / s$ males.

\section{Results and Discussion}

The demand for rice continues to rise because of population growth and improvement in living standards. In last two decades, a number of high yielding varieties were developed and have achieved popularity in the farming community because of being high yielding; however, a yield plateau has been experienced for the last few years. Therefore, to devise a breeding methodology to unfold the genetic information for various metric traits is prerequisite. Hybrid rice technology offer an opportunity for vertical growth through increase in productivity due to yield advantage of 15-20 per cent over the conventional high yielding varieties (Virmani, 1996). Since 1979, IRRI and several countries in Asia including India have been exploring the potential and problems of commercial exploitation of heterosis. The knowledge of nature and magnitude of gene actions involved in different quantitative traits is thus necessary for reorientation of breeding methodologies on systematic lines so that a breeder can come to the logical conclusion. Breeder uses these variance components to measure the gene action and to assess the genetic potentialities of parent in hybrid combinations. To break the yield barriers, in the non-existence of scope through horizontal growth, the development of hybrid rice is being

The analysis of variance revealed highly significant mean squares due to treatments, parents, crosses and line $\times$ testers for all the ten characters. The mean squares due to parents vs. crosses, and testers were also significant for all the characters. This indicated presence of substantial variability in the materials and validated further statistical and genetical analysis. For assessment of genetic variability the estimates of coefficients of variation (Burton and de Vane, 1953), heritability in narrow sense (Kempthorne, 1957) and broad sense (Hanson et al., 1956) and genetic advance in per cent of mean (Johnson et al., 1955) were computed. The results obtained in respect of various aspects of the experiment conducted in the present investigation have been described in this chapter under the following sections.

Analysis of variance for design of experiment Mean performance of genotypes

Coefficients of variation

Heritability and genetic advance 
Analysis of variance for design of experiment

Analysis of variance was carried out with respect to ten characters to test the significance of differences between various treatments (genotypes) viz., seven lines, three tester and twenty-one $\mathrm{F}_{1} \mathrm{~s}$, as depicted in Table 1. The mean squares due to treatments were highly significant for all the ten characters indicated the presence of sufficient variability in the study materials.

\section{Mean performances of genotypes}

Mean performance of parents and crosses in respect of ten characters has been presented in Table 2. The character wise results are described below:

The days to $50 \%$ flowering ranged among parents from 92.37 (FL-478) to 109.58 days (Pusa Basmati-1). Among crosses, it varied from 93.68 days (IR-11T-205 x Jaya, IR-11T$205 \times$ CSR-10 and IR-11T-205 x BPT-5204) to 101.24 days (Narendra-2009 $\mathrm{x}$ Jaya, Narendra-2009 x CSR-10 and Narendra-2009 $\times$ BPT-5204). The general mean value (98.59 \pm 0.17 days) was in between the means of the parents (99.23 \pm 0.05 days) and crosses (98.27 \pm 0.02 days).

Plant height of parents varied from 73.23 (IR$11 \mathrm{~T}-205)$ to $125.18 \mathrm{~cm}$ (Narendra - 2026). Among the crosses, plant height ranged from 91.06 (IR-11T-205 $\times$ BPT-5204) to $100.22 \mathrm{~cm}$ (Narendra-2009 $\times$ BPT- 5204). In general, crosses were taller than the parents. The most desirable crosses for dwarf stature were IR $12 \mathrm{~T}-193 \times \mathrm{CSR}-10$ and IR $11 \mathrm{~T}-205 \times \mathrm{BPT}-$ 5204. The general mean $(95.55 \pm 0.18 \mathrm{~cm})$ was in between mean of the parents $(95.32 \pm$ $0.31 \mathrm{~cm})$ and crosses $(95.65 \pm 0.21 \mathrm{~cm})$.

The size of flag leaf area excluding sheath in parents ranged from 18.16 (IR-12T-193) to
$30.66 \mathrm{~cm}^{2}$ (Jaya) with mean of $22.66 \pm 0.19$ $\mathrm{cm}^{2}$ while in crosses it ranged from 21.55 (FL$48 \times$ BPT-5204) to $29.41 \mathrm{~cm}^{2}$ (Narendra-2009 $\times$ Jaya) with a mean of $23.96 \pm 0.13 \mathrm{~cm}^{2}$. The most desirable crosses for flag leaf area were Narendra-2009 x Jaya and Narendra-2009 x CSR-10. The overall mean range of parents including crosses ranged from $18.16 \mathrm{~cm}^{2}$ (IR12T-193) to $29.41 \mathrm{~cm}^{2}$ (Narendra-2009 $\times$ Jaya) with overall mean of $23.54 \pm 0.11 \mathrm{~cm}^{2}$.

Panicle bearing tillers per plant among parents ranged from 5.92 (BPT-5204) to 11.37 (CSR10). Among the crosses, it varied from 8.73 (Pusa Basmati-1 $\times$ BPT-5204) to 11.385 (IR$11 \mathrm{~T}-205 \times$ CSR-10). The best crosses for panicle bearing tillers per plant were Narendra-2009 × Jaya and Narendra-2009 × CSR-10. The general mean $(9.78 \pm 0.18)$ was found within the mean of parents $(8.42 \pm 0.32)$ and crosses $(10.43 \pm 0.23)$.

The panicle length varied from 16.86 (IR-12T193 ) to $23.75 \mathrm{~cm}$ (Narendra- 2026) in parents. Among crosses, it ranged from 20.95 (IR-12T193× CSR-10) to $24.14 \mathrm{~cm}$ (Pusa Basmati-1 $\times$ CSR-10).

The best crosses for panicle length were Pusa Basmati-1 $\times$ CSR-10 and Narendra-2009 $\times$ CSR-10. The general mean for panicle length $(22.14 \pm 0.08 \mathrm{~cm})$ was in between mean of parents $(21.03 \pm 0.16 \mathrm{~cm})$ and crosses $(22.67 \pm$ $0.11 \mathrm{~cm})$.

Among parents, minimum and maximum grains per panicle were recorded in FL-478 (91.72) and CSR-10 (135.25), respectively. It varied from 96.94 (Pusa Basmati-1 $\times$ BPT$5204)$ to 138.01 (Narendra-2009 $\times$ CSR-10) among the crosses. The most desirable crosses for grain per panicle were Narendra-2009 $\times$ CSR-10 and IR 11T-205 $\times$ CSR-10. The general mean $(114.96 \pm 0.61)$ was in between mean of parents $(101.95 \pm 1.07)$ and crosses (121.15 \pm 0.74$)$. 
Table.1 Analysis of variance for randomized block design for ten characters in rice

\begin{tabular}{|c|c|c|c|c|c|c|c|c|c|c|}
\hline \multirow{2}{*}{$\begin{array}{l}\text { S. } \\
\text { N. }\end{array}$} & \multirow{2}{*}{ Characters } & \multicolumn{9}{|c|}{ Source of variation } \\
\hline & & Replications & Treatments & Parents & Crosses & $\begin{array}{l}\text { Parents Vs } \\
\text { Crosses }\end{array}$ & Lines & Testers & $\begin{array}{l}\text { Lines x } \\
\text { Testers }\end{array}$ & Error \\
\hline & d.f. & 2 & 30 & 9 & 20 & 1 & 6 & 2 & 1 & 60 \\
\hline 1 & Days to $50 \%$ flowering & 1.38 & $112.71 * *$ & $194.02 * *$ & $80.83 * *$ & $18.65^{* *}$ & 185.03 & 273.38 & 89.29 & 2.57 \\
\hline 2 & Plant height $(\mathrm{cm})$ & 1.04 & $291.81 * *$ & $792.82 * *$ & $80.83 * *$ & 2.21 & 1061.48 & 154.10 & 158.29 & 2.88 \\
\hline 3 & Flag leaf area $\left(\mathrm{cm}^{2}\right)$ & 0.44 & $28.13 * *$ & $16.75 * *$ & $32.93 * *$ & $34.45 * *$ & 23.45 & 4.95 & 0.19 & 1.06 \\
\hline 4 & Panicle bearing tillers per plant & 0.008 & $17.29 * *$ & $8.37 *$ & $18.08 * *$ & $81.98 * *$ & 11.30 & 3.18 & 1.16 & 3.31 \\
\hline 5 & Panicle length $(\mathrm{cm})$ & 0.46 & $13.65 * *$ & $14.74 * *$ & $11.08 * *$ & $55.23 * *$ & 17.72 & 3031 & 19.73 & 0.75 \\
\hline 6 & Grains per panicle & 9.65 & $1283.82 * *$ & $728.23 * *$ & $1223.64 * *$ & $7487.74 * *$ & 747.33 & 1035.03 & 0.06 & 34.61 \\
\hline 7 & 1000- grain weight (g) & 0.39 & $16.56 * *$ & $16.79 * *$ & $16.61 * *$ & $13.45 * *$ & 18.24 & 13.83 & 14.09 & 0.55 \\
\hline 8 & Biological yield per plant (g) & 7.42 & $339.71 * *$ & $79.92 * *$ & $341.99 * *$ & $2632.41 * *$ & 77.46 & 126.14 & 2.23 & 7.39 \\
\hline 9 & Harvest-index (\%) & 4.05 & $17.31 * *$ & $5.83^{*}$ & $20.39 * *$ & $58.91 * *$ & 7.89 & 2.54 & 0.09 & 2.71 \\
\hline 10 & Grain yield per pant (g) & 3.32 & $73.52 * *$ & $14.76 * * *$ & $74.92 * *$ & $574.38 * *$ & 17.24 & 14.64 & 0.12 & 1.41 \\
\hline
\end{tabular}

*, **: Significant at $5 \%$ and $1 \%$ probability levels, respectively.

Table.2 Mean and range of parents, crosses and parents including crosses for ten traits in rice under sodicity

\begin{tabular}{|c|c|c|c|c|c|c|c|}
\hline \multirow[t]{2}{*}{ S.N. } & \multirow[t]{2}{*}{ Trait per Generation } & \multicolumn{2}{|c|}{ Parent } & \multicolumn{2}{|c|}{ Cross } & \multicolumn{2}{|c|}{ Parent including cross } \\
\hline & & Mean & Range & Mean & Range & Mean & Range \\
\hline 1 & Days to $50 \%$ flowering & $99.23 \pm 0.05$ & $92.37-109.58$ & $98.27 \pm 0.02$ & $93.68-101.24$ & $98.59 \pm 0.17$ & $92.37-109.58$ \\
\hline 2 & Plant height $(\mathrm{cm})$ & $95.32 \pm 0.31$ & $73.23-125.18$ & $95.65 \pm 0.21$ & $91.063-100.22$ & $95.55 \pm 0.18$ & $73.23-125.18$ \\
\hline 4 & Panicle bearing tillers per plant & $8.42 \pm 0.33$ & $5.92-11.37$ & $10.43 \pm 0.23$ & $8.73-11.85$ & $9.78 \pm 0.18$ & $5.92-11.85$ \\
\hline 5 & Panicle length $(\mathrm{cm})$ & $21.03 \pm 0.16$ & $16.86-23.75$ & $22.67 \pm 0.11$ & $20.95-24.14$ & $22.14 \pm 0.08$ & $16.86-24.14$ \\
\hline 6 & Grains per panicle & $101.95 \pm 1.07$ & $91.72-135.25$ & $121.15 \pm 0.74$ & 96.94-138.01 & $114.96 \pm 0.61$ & $91.72-138.01$ \\
\hline 8 & Biological yield per plant (g) & $36.55 \pm 0.49$ & $26.68-62.59$ & $47.93 \pm 0.34$ & $39.63-58.56$ & $44.26 \pm 0.28$ & $26.68-58.56$ \\
\hline 9 & Harvest-index (\%) & $39.39 \pm 0.30$ & $37.04-45.63$ & $41.09 \pm 0.20$ & $38.07-43.98$ & $40.55 \pm 0.17$ & $37.04-43.98$ \\
\hline 10 & Grain yield per pant (g) & $14.45 \pm 0.22$ & $9.88-26.62$ & $19.77 \pm 0.15$ & $15.56-25.34$ & $18.05 \pm 0.12$ & $9.88-25.34$ \\
\hline
\end{tabular}


Table.3 Estimates of Phenotypic (PCV) and genotypic (GCV) coefficient of variation, heritability and genetic advance in per cent of mean for ten characters in rice

\begin{tabular}{|c|c|c|c|c|c|c|c|c|c|c|}
\hline \multirow{3}{*}{$\begin{array}{l}\text { S. N. } \\
1\end{array}$} & \multirow{3}{*}{$\begin{array}{l}\text { Character } \\
\text { ws to } 50 \% \\
\text { wering }\end{array}$} & \multicolumn{2}{|c|}{$\begin{array}{c}\text { Coefficient of variation } \\
(\%)\end{array}$} & \multicolumn{2}{|c|}{ Heritability (\%) } & \multicolumn{2}{|c|}{ Genetic component } & \multirow[t]{2}{*}{$\begin{array}{l}\text { Degree of } \\
\text { dominance }\end{array}$} & \multirow{2}{*}{$\begin{array}{c}\text { Genetic } \\
\text { advance } \\
(5 \%)\end{array}$} & \multirow{2}{*}{$\begin{array}{c}\text { Genetic } \\
\text { advance in \% } \\
\text { of mean }\end{array}$} \\
\hline & & \multirow{2}{*}{\begin{tabular}{|c|} 
Genotypic \\
6.047 \\
\end{tabular}} & \multirow{2}{*}{\begin{tabular}{|c|} 
Phenotypic \\
6.26 \\
\end{tabular}} & \multirow{2}{*}{$\begin{array}{c}\text { Broad sense } \\
\left.\mathbf{( h}_{\mathbf{b s}}^{\mathbf{2}}\right)\end{array}$} & \multirow{2}{*}{\begin{tabular}{|c|}
$\begin{array}{c}\text { Narrow } \\
\text { sense }\left(\mathbf{h}^{\mathbf{2}}{ }_{\mathbf{n s}}\right)\end{array}$ \\
49.51
\end{tabular}} & \multirow{2}{*}{$\begin{array}{c}\text { Additive } \\
\operatorname{variance}\left(\boldsymbol{\sigma}_{\mathbf{A}}^{\mathbf{2}}\right) \\
2.29 \\
\end{array}$} & \multirow{2}{*}{$\begin{array}{c}\begin{array}{c}\text { Dominance } \\
\text { variance }\left(\boldsymbol{\sigma}_{\mathbf{D}}^{\mathbf{2}}\right)\end{array} \\
75.04\end{array}$} & & & \\
\hline & & & & & & & & 5.72 & 11.87 & 12.04 \\
\hline 2 & Plant height $(\mathrm{cm})$ & 10.15 & 10.306 & 97.00 & 46.46 & 2.69 & 69.49 & 5.08 & 19.73 & 20.60 \\
\hline 3 & $\begin{array}{l}\text { Flag leaf area } \\
\left(\mathrm{cm}^{2}\right)\end{array}$ & 12.55 & 13.27 & 89.4 & 65.18 & 2.19 & 14.35 & 2.55 & 5.76 & 24.45 \\
\hline 4 & $\begin{array}{l}\text { Panicle bearing } \\
\text { tillers per plant }\end{array}$ & 21.82 & 28.69 & 57.9 & 57.08 & 0.84 & 8.99 & 3.28 & 3.33 & 34.19 \\
\hline 5 & $\begin{array}{l}\text { Panicle length } \\
(\mathrm{cm})\end{array}$ & 9.301 & 10.08 & 85.1 & 34.87 & 0.06 & 12.95 & 14.19 & 3.91 & 17.68 \\
\hline 6 & Grains per panicle & 17.46 & 18.18 & 92.2 & 67.66 & 72.55 & 65.68 & 3.00 & 39.70 & 34.54 \\
\hline 7 & $\begin{array}{l}\text { 1000- grain } \\
\text { weight }(\mathrm{g})\end{array}$ & 9.76 & 10.27 & 90.3 & 49.93 & 0.42 & 16.04 & 6.18 & 4.45 & 19.11 \\
\hline 8 & $\begin{array}{l}\text { Biological yield } \\
\text { per plant }(\mathrm{g})\end{array}$ & 23.409 & 24.18 & 93.7 & 63.69 & 16.59 & 233.78 & 3.75 & 20.65 & 46.68 \\
\hline 9 & $\begin{array}{l}\text { Harvest-index } \\
(\%)\end{array}$ & 5.29 & 6.78 & 61.1 & 61.70 & 1.15 & 8.80 & 2.76 & 3.46 & 8.53 \\
\hline 10 & $\begin{array}{l}\text { Grain yield per } \\
\text { pant }(\mathrm{g})\end{array}$ & 26.75 & 27.54 & 94.4 & 69.27 & 4.36 & 42.21 & 3.11 & 9.65 & 53.54 \\
\hline
\end{tabular}


Among parents, minimum and maximum 1000-grain weight was recorded in IR-11T205 (19.65 g) and IR-12-193 (26.27 g), respectively. In crosses, it varied from $22.29 \mathrm{~g}$ (Pusa Basmati-1 $\times$ BPT-5204) to $25.25 \mathrm{~g}$ (IR11T-205 $\times$ CSR-10 and IR-11T-205 × Jaya). The best crosses for 1000-grain weight were Narendra-2009 $\times$ Jaya and IR-11T-205 $\times$ CSR-10. The general mean $(23.30 \pm 0.08 \mathrm{~g})$ was in between the mean of parents $(22.75 \pm$ $0.14 \mathrm{~g})$ and crosses $(23.56 \pm 0.09 \mathrm{~g})$.

Biological yield per plant ranged from 26.68 (Pusa Basmati-1) to 62.59 g (CSR-10) among parents and from 39.63 (Pusa Basmati-1 $\times$ BPT-5204) to $58.56 \mathrm{~g}$ (Narendra-2009 $\times$ CSR-10) in crosses. The best crosses were Narendra-2009 $\times$ CSR-10 and Narendra -2026 $\times$ CSR -10 . The grand mean $(44.26 \pm 0.28 \mathrm{~g})$ was in between the mean of parents $(36.55 \pm$ $0.49 \mathrm{~g})$ and crosses $(47.93 \pm 0.34 \mathrm{~g})$.

Among parents, minimum and maximum harvest index was recorded in Pusa Basmati-1 (37.04\%) and CSR-10 (45.63\%), respectively. In crosses, it varied from 38.07 (Narendra $2026 \times$ CSR-10) to $43.98 \%$ (Narendra $2009 \times$ CSR-10).

The most desirable crosses for harvest index were Narendra-2009 $\times$ CSR-10 and Narendra$2009 \times$ Jaya. The general mean (40.55 \pm $0.17 \%$ ) was in between the mean of parents $(39.39 \pm 0.30 \%)$ and crosses $(41.09 \pm 0.20 \%)$.

Grain yield per plant ranged from 9.88 (Pusa Basmati-1) to $26.62 \mathrm{~g}$ (Jaya) in parents and in crosses from 15.56 (Pusa Basmati-1 $\times$ BPT5204) to $25.34 \mathrm{~g}$ (Narendra $2009 \times$ CSR-10).

The most desirable crosses for grain yield per plant were Narendra-2009 $\times$ CSR-10 and Narendra-2009 $\times$ Jaya. The grand mean $(18.05 \pm 0.12 \mathrm{~g})$ was in between the mean of parents $(14.45 \pm 0.22 \mathrm{~g})$ and crosses $(19.77 \pm$ $0.15 \mathrm{~g})$.

\section{Coefficients of variation}

The phenotypic (PCV) and genotypic (GCV) coefficients of variation for the ten characters under study have been presented in Table 3 . In general, the magnitude of phenotypic coefficient of variation was higher than the corresponding genotypic coefficient of variation for all the traits. The high estimates of phenotypic and genotypic coefficient of variation $(>20 \%)$ were recorded for panicle bearing tillers per plant, biological yield per plant and grain yield per plant. The moderate estimates (10-20\%) of PCV and GCV were recorded for plant height, flag leaf area and grains per panicle. Days to $50 \%$ flowering, panicle length, 1000-grain weight and harvest index $(\%)$ showed low estimates $(<10 \%)$ for both the parameters. The high estimates of direct selection parameters observed for the above characters are in close agreement with the earlier reports in rice (Suman et al., 2005; Panwar et al., 2007; Babar et al., 2009; Arvind et al., 2011; Yadavendra et al., 2011; Kiani and Nematzadeh, 2012 and Singh et al., 2012).

\section{Heritability and genetic advance}

The estimates of heritability in broad sense $\left(\mathrm{h}_{\mathrm{bs}}^{2}\right)$ and genetic advance in per cent of mean estimated for ten characters have been presented in Table 3. High estimates of broad sense heritability $(>75 \%)$ was recorded for all the characters except panicle bearing tillers per plant and harvest-index, which exhibited moderate estimate of heritability $(50-75 \%)$. High to low estimates of heritability has also been reported by Kumar et al., (2011) for different characters in rice.

The genetic advance in per cent of mean was not found to be very high $(>50 \%)$ for any character except grain yield per plant. However, high estimates of $\mathrm{h}^{2}$ bs $(>20-50 \%)$ was observed for all characters and moderate 
(>10-20\%) genetic advance in per cent of mean was observed for days to $50 \%$ flowering, panicle length and 1000-grain weight. High heritability coupled with high genetic advance in per cent of mean were observed for grain yield per plant, biological yield per plant, plant height, grins per panicle, panicle bearing tillers per plant and flag leaf area $\left(\mathrm{cm}^{2}\right)$. The high estimates of direct selection parameters observed for the above characters are broadly in agreement with earlier reports in rice (Mall et al., 2005; Suman et al., 2005; Singh et al., 2006; Panwar et al., 2007; Babar et al., 2009).

The experiment was based on evaluation of a line $\mathrm{x}$ testers set of 21 hybrids $\left(\mathrm{F}_{1}\right.$ 's) and their 10 parents ( 7 lines and 3 testers), a total of 31 treatment along with one standard variety (Narendra Usar-3) for ten characters under salt affected soil in Randomized Block Design with three replication during kharif 2016. The $21 \mathrm{~F}_{1}$ 's were generated by crossing 3 testers with 7 lines during kharif - 2015. Observations on 10 metric traits were recorded for various statistical and biometrical analyses. The data of ten characters was subjected to analysis of variance for Randomized Block Design (Panse and Sukhatme, 1967); computation of heritability in narrow-sense (Kempthorne, 1957); and genetic advance in per cent of mean (Johnson et al., 1955)

The salient findings of present study are summarized below:

Analysis of variance exhibited significant differences among the treatments, parents and crosses for all the traits under study.

High heritability along with high genetic advance in percentage of mean was recorded for biological yield per plant followed by grains per panicle and panicle bearing tillers per plant reflecting additive gene action.
Hence, the emphasis should be given to select these traits directly to enhance the breeding programme. Remaining traits possessed nonadditive gene action.

\section{Acknowledgement}

The authors are thankful to Dr. P.K. Singh, Professor and Head of the Department, Genetics and Plant Breeding, Narendra Deva University of Agriculture and Technology, Kumarganj, Faizabad for providing research field and all essentials. In addition, the authors thank Nayana P. Department of Biotechnology, Kuvempu University, shivmogga for suggestion and Prakash V. K. and Annapurna R. for financial support.

\section{References}

Arvind Kumar, Hitesh Kumar, Vikas Gupta, GauravKhosla and Sharma, P. K. (2011). Correlation and path coefficient analysis for yield and yield component traits rice (Oryza sativa L.). Agril. Sci. Digest, 31 (4): 275-279.

Babar, M., Khan, A. A., Arif, A., Zafar, Y. and Arif, M. (2009).Path analysis of some leaf and panicle traits affecting grain yield in double haploid lines of rice (Oryza sativa L.). J. Agric. Res., 45 (4): 245-252.

Burton, L.D. and de Vane (1953). Estimating heritability in tall fescus (Festuca arundinacea) from replicated clonal material. Agron J., 45:478-481.

Hanson, C.H., Robinson, H.F. and Comstock, R.E. (1956). Biometrical studies of yield in segregating population of Korean Lespedeza. Agron. J., 45: 268272.

Johnson, H.W., Robinson, H.F. and Comstock, R.E. (1955).Estimates of genetic and environmental variability in soybean. Agron. J., 47: 314-318. 
Johnson, H.W., Robinson, H.F. and Comstock, R.E. (1955).Estimates of phenotypic and genotypic correlation in soybean and their implications in selection. Agron. J., 47: 477-483

Kempthorne, O. (1957). An Introduction to Genetical Statistics. John Wiley and Sons Inc. New York, pp. 468-471.

Khush, G.S. (1997). Origin, dispersal, cultivation and variation of rice. Plant Mol. Biol., 35: 25-34.

Kiani, G. (2013). Heritability and diversity analysis of quantitative traits in rice. Agriculturae Conspectus Scientificus (Poljoprivredna Znanstvena Smotra), 78 (2):113-117.

Kumar, Y., Singh, B.N., Verma, O.P., Tripathi, S. and Dwivedi, D.K. (2011). Correlation and path coefficient analysis in scented rice (Oryza sativa L.) under sodicity. Environment and Ecology, 29 (3B):1550-1556.

Moll, R.N. and Stuber, C.W. (1974). Quantitative genetics results relevant to plant breeding. Adv. Agron., 26:277313.

Panse, V.G. and Shukhatme, P.V. (1967).Statistical methods for Agricultural workers, II ${ }^{\text {nd }}$ Ed. ICAR, New Delhi, 381.

Panwar, A., Dhaka, R. P. S. and Kumar, V. (2007).Genetic variability and heritability studies in rice. Advances in Plant Sci., 20 (1): 47-49.
Poehlman, J.M. 1987. Breeding Field Crops.III Edition. AVI Publ. Co. Westport, Connecticut. Pp. 340-377.

Saleem, M. Y., Mirza, J. I. and Haq, M. A. (2008). Heritability, genetic advance and heterosis in line $\mathrm{x}$ tester crosses of Basmati rice.J. Agric. Res., 46 (1): 1526.

Singh, P. K., Dhakad, B. K., Singh, H. B. and Singh, A. K. (2012).Genetic variability and association analysis in rice (Oryza sativa L.) treated with Trichoderma harzianum. Crop Research (Hisar), 44 (1/2): 141-145.

Suman, A., Shankar, V. G., Rao, L. V. S. and Sreedhar, N. (2005).Variability, heritability and genetic advance in rice (Oryza sativa L.).Crop Res. (Hisar), 30 (2): 211-214.

Virmani, S.S. (1996). Hybrid rice. Advan. In Agron., 57: 328-462.

Yadavendra Kumar, Singh, B. N., Singh, P. K., Shweta Tripathi, Dwivedi, D. K. and Nalini Tewari (201). Genetic variability and parameters for direct selection of scented rice (Oryza sativa) in different environments. Current Advances in Agril. Sci., 4 (2):168-170

Yuan, L. P. (1966). Preliminary report on the male sterility in rice. Bullet, 4: 32-34.

Yuan, L. P. and Virmani, S. S. (1988). Status of hybrid rice research and development. In: Hybrid Rice, International Rice Research Institute, Manila, Philippines, pp 7-24.

\section{How to cite this article:}

Hamsa Poorna Prakash, O.P. Verma and Amit Kumar Chaudhary. 2018. Genetic Variability, Heritability and Genetic Advance in Rice (Oryza sativa L.) under Salt Affected Soil. Int.J.Curr.Microbiol.App.Sci. 7(05): 3183-3192. doi: https://doi.org/10.20546/ijcmas.2018.705.372 